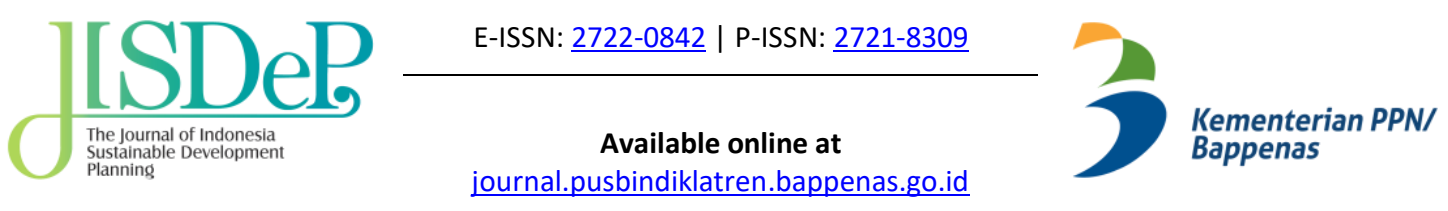

Editorial Notes

\title{
Covid 19 and Environment: How We Can Learn for Environmental Management
}

Since the World Health Organization (WHO) announced the pandemic covid 19 as a global pandemic on March 2020, as of 6 August 2021, the aggregate number of Covid 19 confirmed cases had exceeded 200.6 million, and more than 200 countries and regions have been affected. In Indonesia, the first case of Covid 19 was reported in March 2020, and the accumulative number of confirmed cases reached around 3.6 million cases on August 2021 in all 34 provinces (World Health Organization, 2021). Not only does the outbreak of Covid 19 threaten public health, but it also impedes economic growth. According to the World Bank (2021), the global economy contracted at around 3.5 percent in 2020. Amongst the advance and emerging market economic groups, Euro Area, Latin America, and the Caribbean (Brazil, Mexico, Argentina) have experienced the lowest economic growth, which was around -6.6 and -6.5 percent, respectively. Generally, the economic contraction during the pandemic is induced by two factors, massive supply shocks and the reduction of demand for goods and services. These factors are mainly triggered by the policy taken by countries to strictly control people's movement and reduce the spread of Covid 19 and the surge in the uncertainty of economic development that leads to the turbulence of capital and financial markets (McKibbin \& Fernando, 2020; Fernandes, 2020).

Despite the negative impacts of the Covid 19 pandemic on the economy, public health, and other sectors, the pandemic shows intriguing impacts on the environment in some aspects, such as air pollution and wildlife (Manan et al., 2020). Existing research shows that as the economic growth declines, the pollution diminishes, and vice versa (Raupach et al., 2007; Wang et al., 2019; Wang \& Su, 2020). During the pandemic, the air quality increases due to the significant reduction in industrial activities, urban transportation, and energy consumption. According to Patel (2020), the pandemic remarkably improved air quality, particularly in the areas that strictly employ lockdown and quarantine measures. Globally, $\mathrm{CO}_{2}$ and $\mathrm{NO}_{2}$ emissions decrease during the pandemic by 25 and 35 percent, respectively. In the Southeast Asian Region, it is reported that three months after the outbreak, there is an improvement in air quality. $\mathrm{NO}_{2}$ emission in major cities such as Jakarta, Kuala Lumpur, and Bangkok shrinks by 34, 27, and 22 percent, respectively (Kanniah et al., 2020).

A study conducted by Wang \& Su (2020a) shows an improvement in the air quality in China, and it significantly contributed to the reduction of global GHG emissions. The reduction in energy consumption, particularly from coal, is the main factor that contributes to the air quality. During the outbreak of Covid

\section{ARTICLE INFO}

Received: August 12, 2021

Received in revised form: August

15,2021

Accepted: August 15, 2021
JISDeP - The Journal of Indonesia Sustainable Development Planning Published by Centre for Planners' Development, Education, and Training (Pusbindiklatren),

Ministry of National Development

Planning/ National Development

Planning Agency (Bappenas), Republic of Indonesia
Address: Jalan Proklamasi 70,

Central Jakarta, Indonesia 10320

Phone: +62 21 31928280/31928285

Fax: +62 2131928281

E-mail:

journal.pusbindiklatren@bappenas.go.id

Supported by Indonesian Development Planners Association (PPPI) 
19 , the concentration of $\mathrm{NO}_{2}$ reduces by 25 percent, while $\mathrm{CO}_{2}$ concentration declines by 6.2 percent. However, the positive effects of the pandemic on air quality only occur in the short term during the quarantine. As some regions lifted the lockdown, industries resumed production, people movement increased, and energy consumption was in an upward trend. The air quality might decline, and it is predicted to exceed the level before the outbreak. In Indonesia, research on the impact of the Covid 19 pandemic is still limited. Caraka et al. (2020) investigated $\mathrm{HCNO}, \mathrm{CO}, \mathrm{NO}_{2}$, and $\mathrm{SO}_{2}$ density five months after the outbreak. The study shows that there is a significant difference in $\mathrm{HCNO}, \mathrm{NO}_{2}$, and $\mathrm{CO}$ density in Jakarta, East Java, and Sulawesi. In contrast, the $\mathrm{SO}_{2}$ density remains the same before and after the outbreak.

The outbreak of Covid 19 also has a significant impact on wildlife. The quarantine measures and the reduction of people movement reduce the number of visitors to national parks and other ecotourism areas. As a result, human intervention in wildlife might be minimized. The Ministry of Environment and Forestry (2020) states that even though there is a reduction in the revenue from ecotourism, there is an improvement in the ecosystem of almost all national parks in Indonesia when the areas are closed for visitors. Moreover, some animals that are not seen for many years were spotted wandering in certain areas. However, the negative impacts of the pandemic on wildlife cannot be ignored, particularly the impact on ex-situ conservations where the feeding of the animal dramatically relies on the visitors. A prolonged pandemic might significantly endanger wild animals due to the lack of food.

The pandemic of Covid 19 provides many lessons to learn on how we can manage our environment in the future. With a specific intervention, the air quality and wildlife could be improved. The positive impacts of the pandemic on the environment offer a guide for policymakers to design standards, operations, and procedures for preserving and protecting the natural environment to minimize the negative impacts of climate change in the future. It is predicted that the magnitude of the impacts of climate change will be much bigger than the outbreak of Covid 19. However, with proper actions, we could mitigate the risks and minimize their impacts.

Dadang Jainal Mutaqin, Ph.D

(Editorial Board)

\section{Reference}

Caraka, R. E., Lee, Y., Kurniawan, R., Herliansyah, R., Kaban, P. A., Nasution, B. I., Gio, P. U., Chen, R. C., Toharudin, T., \& Pardamean, B. (2020). Impact of COVID-19 large scale restriction on environment and economy in Indonesia. Global Journal of Environmental Science and Management, 6(Special Issue), 6584. https://doi.org/10.22034/GJESM.2019.06.SI.07

Fernandes, N. (2020). Economic effects of coronavirus outbreak (covid-19) on the world economy. SSRN Electronic Journal, 0-29. https://doi.org/10.2139/ssrn.3557504

Kanniah, K. D., Zaman, N. A. F. K., Kaskaoutis, D. G., \& Latif, M. T. (2020). Covid-19's impacts of the atmosperic environment in the Southeast Asian region. Sience of the Total Environment, 736, 138658. https://doi.org/10.1016/J.SCITOTENV.2020.139658

Manan, S., Ullah, M. W., Guo, Z., \& Yang, G. (2020). Impact of covid-19 on environment sustainability. ES Energy and Environment, 8, 1-2. https://dx.doi.org/10.30919/esee8c378

McKibbin, W., \& Fernando, R. (2020). The global macroeconomic impacts of covid-19: Seven scenarios. Asian Economic Papers, 20(2), 2-30. https://doi.org/10.1162/asep_a_00796

Ministry of Environment and Forestry. (2020). Impacts of Covid 19 on ecotourism and national parks management. FGD on Impacts of Covid-19 on Conservation Area Management, Jakarta.

Patel, K. (2020). Airborne Nitrogen Dioxide Plummets Over China. NASA Earth Observatory. https://earthobservatory.nasa.gov/images/146362/airbornenitrogen- dioxide-plummets-overchina?utm=carousel

Raupach, M. R., Marland, G., Ciais, P., Le Quéré, C., Canadell, J. G., Klepper, G., \& Field, C. B. (2007). Global and regional drivers of accelerating $\mathrm{CO} 2$ emissions. Proceedings of the National Academy of Sciences of the United States of America, 104(24), 10288-10293. https://doi.org/10.1073/pnas.0700609104 
Wang, Q., \& Su, M. (2020a). A preliminary assessment of the impact of COVID-19 on environment-A case study of China. Science of the Total Environment, 728, 138915. https://doi.org/10.1016/j.scitotenv.2020.138915

Wang, Q., \& Su, M. (2020b). Drivers of decoupling economic growth from carbon emission - an empirical analysis of 192 countries using decoupling model and decomposition method. Environmental Impact Assessment Review, 81, 106356. https://doi.org/10.1016/j.eiar.2019.106356

Wang, Q., Su, M., Li, R., \& Ponce, P. (2019). The effects of energy prices, urbanization and economic growth on energy consumption per capita in 186 countries. Journal of Cleaner Production, 225, 1017-1032. https://doi.org/10.1016/j.jclepro.2019.04.008

World Bank. (2021). Global Economic Prospects. World Bank Group. https://doi.org/10.1596/978-1-46481612-3

World Health Organization. (2021). Coronavirus disease (COVID-19) pandemic. WHO. https://www.who.int/emergencies/diseases/novel-coronavirus2019? adgroupsurvey $=\{$ adgroupsurvey $\}$ gclid=CjwKCAjwpMOIBhBAEiwAy5M6YOROGbPu_Ebv9mcru TEzHxJJImezOhJMLvtm4aWn9J8Th6_17mp08hoCTQAQAvD_BwE 